\title{
Enhancement of Crude Oil Biodegradation by Immobilized Bacterial Consortium in Small Batch and Continuous Bioreactor Modes
}

\author{
Soha Farag1*, Nadia A. Soliman², Yasser R. Abdel-Fattah ${ }^{2}$ \\ ${ }^{1}$ Environmental Biotechnology Department, Genetic Engineering and Biotechnology \\ Research Institute, City of Scientific Research and Technological Applications, \\ Alexandria, Egypt. \\ ${ }^{2}$ Bioprocess Development Department, Genetic Engineering and Biotechnology \\ Research Institute, City of Scientific Research and Technological Applications, \\ Alexandria, Egypt.
}

\begin{abstract}
O IL SPILLS besides the discarding of oil refineries byproducts directly into the environment is a major source of nature pollution which contributes to environmental contamination and health problems. Firstly for solving this problem oil degrading bacterial consortium (Pseudomonas sp. sp48 and Bacillus cereus M12 which were isolated from soil samples from Bahary area, SidiKerir branch, Alexandria, Egypt, respectively) was immobilized with different carriers, where rice straw was selected as the best one for oil degradation. Conditional optimization for immobilized bacterial consortium has been explored by testing various amounts of preculture $(2,3,4,5.5$ and $7 \%)$, different incubation time with rice straw (1-5 h), enumeration of viable cells immobilized and different oil concentrations $(1,2,3$, and $4 \%$ ). The degradation of crude oil ( $1 \%$ concentration) reached to $61.6 \%$ due to biological action alone while it raised to $97.14 \%$ by binary actions of biological and physical after 6 days incubation time and applying the optimum conditions ( $4 \%$ bacterial consortium preculture and $3 \mathrm{~h}$ incubation time with the carrier). Finally application study has been carried out using the ideal model conditions in small batch bioreactor and continuous to treat oil contaminated water in an open system. The results showed that the crude oil degradation biologically only and biologically/ physically reached to $56.2 \%$ and $87.2 \%$, respectively. Whereas the continuous addition of $1 \%$ oil concentration for three times the removal reached to $81.27 \%$. This technique of immobilization produces a promising result for solving the oil pollution problem due to the collaborating effects for both physical and biological actions.
\end{abstract}

Keywords: Biodegradation, Crude oil, Bacteria, Immobilization, Bioreactor.

\section{Introduction}

Crude oil is a very important mineral resource vital to everyday life. However, crude oil spillage is one of the most serious forms of water and land pollution. Oil spillage is the accidental discharge or pouring of crude oil into the environment. It involves the contamination of any part of the environment with any liquid hydrocarbon. These spills endanger public health, imperil drinking water, devastate natural resources, pollute beach and shorelines, and disrupt the economy [1].

Biodegradation of crude oil is not a new technology for combating oil pollution. Isolation of active oil-degrading bacteria from the marine environment was conducted as early as 1960s [2]. There are many challenges to recover oilpolluted sediment or water by inoculating oildegrading bacteria like nutrient deficiency which was identified as one of the limiting factors in oil degradation [3, 4]. Although nutrients-enrichment helps the bioremediation, it is not the only compel in oil degradation. Factors such as inhibitive metabolites and the ability of the oil degrading microorganisms are among other reasons that retard biodegradation [5]. Biodegradation involved a series of complicated biochemical reactions which cannot be done by an only one

*Corresponding author e-mail: sohafarag88@yahoo.com

Tel.: (203)4593418; fax: (203)4593407.

DOI: $10.21608 /$ EJCHEM.2018.3820.1336

(C)2017 National Information and Documentation Centre (NIDOC) 
organism. Importance of the bacterial consortium for bioremediation was highlighted in many reports [6]. Ito et al [7] reported a consortium of symbiotic bacteria, which are capable of degrading microbial-resistant turbine engine oil; and $\mathrm{Li}$ et al [8] reported a microbial consortium of bacteriafungi complex capable of degrading more than $50 \%$ of aged polycyclic aromatic hydrocarbons in soil and slurry. Radwan et al [9] reported the superior performance of oil-consuming microbial consortia in the Arabian Gulf.

The most important limiting factor is the inhibition effect of high oil concentration on the microorganism. According to William [10], who reported that the using of carriers, mainly in the sea or in non-accessible areas, such as marshes or flooded zones is the most common practices for oil spill remediation or oil recovery. Synthetic products such as polypropylene, polyurethane, foam, polyethylene terephthalate and teflon are the most used materials due to their low cost, high availability and high oil-sorption capacities. Inorganic mineral products as perlite, vermiculite, dolomite and graphite are also used [11, 12]. Finally the agriculture wastes as corn leaves, cane leaves, rice straw and wood chips which economically cheap, renewable supports and high oil sorption capacities will be extensively studied in our work for oil removal.

Oil carriers can adsorb and concentrate floating petroleum and prevent its migration to shorelines and beaches. If oil carriers were immobilized with oil degrading bacteria, bioremediation may occur in situ or ex situ [13].

The use of immobilization technique involving carrier materials for the delivery of microbial cells to natural ecosystems is an attractive option. Carrier materials are generally intended to provide protective niche to microbial inoculants, either physically, through the donation of a pore space or protective surface, or nutritionally, through the donation of a specific substrate. An optimum carrier should provide favorable conditions for survival and activity of the inoculant cells [14]. The carrier should, additionally, be nontoxic, nonpolluting, have a constant quality and be locally available at low price [15-17]. Furthermore carrier inert surfaces in cultures of degrading microorganisms and immobilized cells have been shown to encourage crude oil degradation [18, 19].

Immobilized microorganisms could degrade Egypt. J. Chem. 61, No. 6 (2018) crude oil at a higher initial concentration and for a longer period. In addition, these cells were also protected from harmful effects of toxic wastes. In some previous studies, immobilized cells could be stored for long periods without losing their degrading abilities. The adsorbed oil materials may even be extracted and the adsorbents reused [20].

Immobilization of oil degraders on carriers may therefore solve the problem of dilution of microbes and nutrients in open water. Preventing migration of floating oil, bioremediation or removal of the oil from the sea will significantly decrease this exposure and facilitate the clean-up of an oil spill. Hence, the use of suitable carrier immobilized with oil degraders may assist in the protection of coastal environment [13].

Consequently, this study aims to demonstrate the efficiency of bacterial consortium immobilized on different carriers in oil degradation. The optimum immobilization conditions for the highest degradation are being to assess. As well applying the immobilization technique in a bioreactor to resembling the nature for application in sea water oil spill.

\section{Materials and Methods}

Development of carrier materials

The used carrier materials were divided into two categories, the first one is natural product which economically cheap and renewable supports, have not any benefit in our life as corn leaves, cane leaves, rice straw and wood chips, the other one is a synthetic carrier as foam and wax. The natural carriers were cut before using into small pieces $3-5 \mathrm{~mm}$ then sterilized by autoclaving at $121{ }^{\circ} \mathrm{C}$ for $20 \mathrm{~min}$. but wax and foam were put in oven at $40^{\circ} \mathrm{C}$ for $24 \mathrm{~h}$.

The needed amounts of tested carriers were determined individually by measuring the amount of carrier that covers the surface of Erlenmeyer flask $250 \mathrm{~mL}\left(50 \mathrm{~cm}^{2}\right)$ filled with $50 \mathrm{~mL}$ natural sea water (NSW). The amount of preculture needed to saturate the carrier was determined by immerging each carrier in a constant volume of preculture then determine the amount of adsorbed preculture.

Based on previous statements the used weight of tested carrier (gram)/preculture volume $(\mathrm{mL})$ was $(0.5 / 3.5)$ for rice straw; $(0.3 / 5)$ for corn leaves; $(0.5 / 2.5)$ for cane leaves; $(0.8 / 2)$ for wood chips; $(0.06 / 1)$ for foam and $(1.5 / 1)$ for wax. 


\section{Immobilization on different carriers}

The bacterial isolates Pseudomonas sp. (sp48) and Bacillus cereus (M12) which previously identified as marine oil-degrading bacterial isolates and kept in GeneBank under accession numbers (ac: KP202717\& KP202718) respectively were used in this study. The isolates were cultured in LB medium has the following composition $(\mathrm{g} / \mathrm{L})$ : $5 \mathrm{~g} \mathrm{NaCl}, 10 \mathrm{~g}$ peptone, $5 \mathrm{~g}$ yeast extract, $\mathrm{pH}$ was adjusted to 7 with either $\mathrm{HCl} / \mathrm{NaOH}$. The flasks were incubated for $24 \mathrm{~h}$ at $30{ }^{\circ} \mathrm{C}$ on a rotary shaker operated at $200 \mathrm{rpm}$. The growth of the bacteria was determined spectrophotometry at $600 \mathrm{~nm}$. The resulted culture was used in subsequent experiments.

Each carrier material was placed into a 250 $\mathrm{mL}$ flask containing $50 \mathrm{~mL}$ of Pseudomonas sp. (sp48) culture (constant growth $\mathrm{OD}_{600 \mathrm{~nm}}=1.2$ ). Afterwards, the flasks were incubated at room temperature under shaking $(100 \mathrm{rpm})$ to allow cells to attach to the carrier material (wet formulation) for constant time $3 \mathrm{~h}$. The wet formulation was removed from the flask and rinsed with sterile LB to remove any cells that were not sufficiently adhered to the carrier material. The same method was repeated for strain M12.

\section{Evaluation of oil bioremediation using immobilized bacteria}

In this experiment, bacterial pre-cultures were prepared by allowing Pseudomonas sp. (sp48), Bacillus cereus (M12) strain to grow individually till constant $\mathrm{OD}_{\lambda 600 \mathrm{~nm}}(1.2)$. Also a consortium of them (sp48 and M12) at equal volumes ratio $\left(1: 1 \% ; \mathrm{OD}_{\lambda 600 \mathrm{~nm}}=1.2\right)$ was prepared. The bacterial preculture at concentration $4 \%$ were incubated individually with different carriers (corn leaves, cane leaves, rice straw, wood chips, foam and wax) for $3 \mathrm{~h}$ at room temperature, then the immobilized bacteria was inoculated to $50 \mathrm{~mL}$ natural sea water containing $1 \%$ crude petroleum oil and incubated at $30{ }^{\circ} \mathrm{C}, 200 \mathrm{rpm}$ in shaker incubator for 6 days. The similar experiment was performed without using the bacteria to know the ability of carrier to adsorb oil physically at the same time. Two controls were prepared, the first one contains free bacterial cells kept under the same former conditions, but the second contains $1 \%$ of crude oil only in natural sea water.

To know the biological effect of immobilized bacteria without interference with physical action of carrier, the flask which contains the immobilized bacteria on the carrier was extracted by dichloromethane then sieved by filtration using a mesh sieve then crude petroleum oil consumption was determined gravimetrically as percentage. In case of physical test the carrier which doesn't contain bacteria was sieved first then the decanted natural sea water was extracted. The test was done in replica and the average result was taken. Crude petroleum oil consumption was determined gravimetrically in percentage as described previously by Law et al [21] and Giorgio et al [22] in which the residue oil of each sample was extracted with $100 \mathrm{ml}$ dichloromethane. Then the residue was then transferred into round bottom flasks and concentrated by rotary evaporator (Ika-Heizbed HB-250). Initial weight of the round bottom flasks were weighted after it has been cleaned and dried. After removing dichloromethane, the round bottom flasks were dried at $50^{\circ} \mathrm{C}$ in oven for an hour and then put into desiccator for another hour before weighing with a 3 decimal points balance. The weights difference of flask equals the weight of residual oil. The percent of oil removal was calculated using equation:

$$
\text { removal } \%=\left(\mathrm{W}_{\mathrm{c}}-\mathrm{W}_{\mathrm{s}} / \mathrm{W}_{\mathrm{c}}\right) * 100
$$

where, $\mathrm{W}_{\mathrm{c}}=$ Weight of control $(\mathrm{g} / \mathrm{L})$ and $\mathrm{W}_{\mathrm{s}}=$ Weight of sample $(\mathrm{g} / \mathrm{L})$.

\section{Conditional optimization for immobilized bacterial consortium}

Various amounts of bacterial consortium preculture $(2,3,4,5.5$ and $7 \%$ ) and different incubation period with rice straw $1-5 \mathrm{~h}$ (one hour interval) were tested in order to optimize the parameters affecting oil degradation by bacterial consortium added to natural sea water supplemented with $1 \%$ crude oil.

Firstly $0.5 \mathrm{gm}$ of carrier material (rice straw) covers the surface area of flask is saturated with $3.5 \mathrm{~mL}$ of bacterial consortium preculture in 50 $\mathrm{mL}$ medium. Accordingly, different amounts of culture $(2,3,4,5.5$ and $7 \%)$ were incubated with rice straw for $3 \mathrm{~h}$ afterwards, the free cells were removed by decantation. After that $50 \mathrm{~mL}$ natural sea water contains $1 \%$ crude petroleum oil was added to the immobilized bacteria and incubated at $30{ }^{\circ} \mathrm{C}$, under shaking $(200 \mathrm{rpm})$ for 6 days.

To optimize the incubation period, the carrier material was incubated with the bacterial consortium preculture $\left(\mathrm{OD}_{600 \mathrm{~nm}}=1.2\right)$ for various periods of time. The rice straw $(0.5 \mathrm{gm})$ were placed into the consortium culture $(4 \% ; 2 \mathrm{~mL}$ 
culture: $1.5 \mathrm{~mL}$ distal water; in $50 \mathrm{~mL}$ medium) and incubated to allow the attachment at different time $1,2,3,4$, and $5 \mathrm{~h}$, thus the immobilization of the cells on the rice straw was allowed. Then the immobilized consortium transferred to the experimental flasks containing natural sea water supplemented with $1 \%$ of crude oil and incubates at $30{ }^{\circ} \mathrm{C}$ and $200 \mathrm{rpm}$ in shaker incubator for 6 days.

\section{Enumeration of viable cells immobilized on rice straw}

To count the attached viable cells, $0.1 \mathrm{~g}$ of the formulation sample was suspended in $5 \mathrm{~mL} \mathrm{LB}$ medium. The suspension was agitated vigorously using a vortex mixer for $3 \mathrm{~min}$ to dislodge the immobilized cells. Serial dilutions were made from the supernatant and aliquots of $0.1 \mathrm{~mL}$ were spread on LB plates. The plates were incubated at $30{ }^{\circ} \mathrm{C}$ until colonies appeared $(24-48 \mathrm{~h})$. The colonies were counted to assess the number of viable bacterial consortium cells immobilized on the carrier material. The attachment efficiency was calculated as the fraction of the total viable cells that was immobilized [23]. This was carried out to evaluate the viable cells immobilized on rice straw at different incubation time based on the previous experiment.

\section{Evaluation of immobilized bacterial consortium efficiency}

These experiments were performed to determine the crude oil removal efficiency of carrier materials (rice and foam) with the bacterial consortium (biologically and physically together) and biological effect alone using bacterial consortium (immobilized cells). The oil removal efficiency was determined by adding $4 \%$ preculture which immobilized and incubated with carrier $(0.5 \mathrm{gm}$ of rice or $0.06 \mathrm{gm}$ of foam) for $3 \mathrm{~h}$ then added to $250 \mathrm{~mL}$ flask that contained $50 \mathrm{~mL}$ of natural sea water with different concentrations of crude oil 1, 2, 3, and 4\%. The control of this experiment is the natural sea water with the same different concentrations of crude oil. All flasks were shaken at $200 \mathrm{rpm}$ and $30{ }^{\circ} \mathrm{C}$ in shaker incubator for 6 days. Crude petroleum oil consumption was determined gravimetrically in percentage as described previously by Law et al [21] and Giorgio et al [22].

\section{Follow up crude oil degradation}

Bacterial consortium was cultured in LB medium for $24 \mathrm{~h}$ till $\mathrm{OD}_{600} 1.2$, then used at $4 \%$ for immobilization on rice straw $(0.5 \mathrm{gm})$ for 3 h. The immobilized consortium was transferred Egypt. J. Chem. 61, No. 6 (2018) to the experimental flasks containing natural sea water supplemented with $1 \%$ crude oil then incubated at $30{ }^{\circ} \mathrm{C}$ under shaking $(200 \mathrm{rpm})$ for 12 days. Two flasks were withdrawn each day and the average result of crude oil biologically removed was determined.

\section{Examination of immobilized cells using Scanning Electron Microscope (SEM)}

Three samples were prepared to examine under SEM, rice straw carrier without addition of oil, bacterial consortium immobilized on rice straw after $3 \mathrm{~h}$ incubation time without oil addition, and rice straw carrier with added oil, where bacterial size was measured in the second sample. The samples were sputter coated with gold (Bal-Tec SCD005 Sputter Coater) and examined using a JEOL JSM 6390LV Scanning Electron Microscope.

\section{Application study in a bioreactor}

A small scale reactor (Glass beaker v: $2 \mathrm{~L}$, diameter: $10 \mathrm{~cm}$, height: $15 \mathrm{~cm}$ ) was used to apply the optimized conditions to treat oil contaminated water in open systems.

In this stage, an equivalent weight of carrier and oil similar to flask experiment were used to cover the surface area of the reactor in order to obtain comparable results. The reactor containing $300 \mathrm{~mL}$ natural sea water, $1 \%$ oil $(800 \mu \mathrm{l})$, and $0.8 \mathrm{gm}$ of carrier (rice straw) per $80 \mathrm{~cm}^{2}$ reactor surface area. The reactor was placed on the bench shaker for approaching the sea waves, at room temperature $\left(25^{\circ} \mathrm{C}\right)$ and using natural sea water for resembling the nature for application in sea water oil spill. Water lost in the reactor via evaporation was replaced daily.

A similar reactor was used by Mang et al [24] whose studies were carried out in a series of identical glass-made vessels which had a total volume of $7 \mathrm{~L}$. Each reactor received $5 \mathrm{~L}$ of $25 \%$ slurry, $600 \mathrm{rpm}, 25-30{ }^{\circ} \mathrm{C}, 15 \%$ (v/v) oil, aeration rate up to $2 \mathrm{mg} / \mathrm{L}$.

\section{Batch bioreactor optimization}

All biodegradation experiments in this study were carried out in a series of identical glass-made vessels which had a total volume of $2 \mathrm{~L}$ as described before. The immobilized bacterial consortium on rice straw was prepared at optimum conditions to know its biological effect in oil degradation. The experiment was carried out at different times $(6,9$ and 12 days) and carrier weights (0.8, 1.2 and 1.6 gm) at constant incubation time (6 days), where $0.8 \mathrm{gm}$ of carrier material (rice straw) covers the 
surface area of reactor $\left(80 \mathrm{~cm}^{2}\right)$.

This experiment was performed with immobilized bacteria to know the ability of carrier to adsorb oil physically and degraded biologically at the same time. Two control reactors were prepared, one contains free bacteria (without immobilization) in the same condition, and the other contains $1 \%$ crude oil only in natural sea water.

\section{Continuous bioreactor}

This experiment was carried out to verify the efficiency of immobilized bacterial consortium on rice straw for repeated oil removal. The small scale reactor (2 L) was prepared and filled with $300 \mathrm{~mL}$ natural sea water, 1.6 gm rice straw immobilized with bacterial consortium (Pseudomonas sp. sp48 and Bacillus cereus M12) and 1\% crude oil (800 $\mu l)$ according to reactor surface area $\left(80 \mathrm{~cm}^{2}\right)$. The bioreactor was placed on a bench shaker at room temperature $\left(25^{\circ} \mathrm{C}\right)$ where, $1 \%$ crude oil was added every 3 days to the bioreactor for three times. The test was done in replica and the average result of crude petroleum oil consumption was determined.

\section{$\underline{\text { Results and Discussion }}$}

Investigation of the best carrier used in immobilization

The percentage of oil degradation using Pseudomonas sp. sp48 /or Bacillus cereus M12 immobilized at different carriers was represented in Table 1, the results show that the best carriers for immobilization of tested bacteria were rice straw, cane leaves then corn leaves (natural products), where the oil removal reached to $46 \%$. The synthetic carriers (foam and the wax) not support the biological degradation of oil throw the immobilization process. On the other hand the foam and wax showed higher efficient for oil removal physically rather than biologically. The percentages of oil removal physically reach $98 \%$ and $96 \%$ when using foam and wax, respectively.

Polyurethane foam (PUF) can adsorb and concentrate Arabian light crude (ALC), possibly increasing substrate limitation and product inhibition within PUF as reported by Nawaz et al [25]. Cell division was also slower in the matrix and this could also decrease uptake of substrates and metabolites leading to slow degradation rate [25]. So the foam is efficient for physical removal of crude oil not as carrier for biodegradation.

It was found in this study the immobilized experimental bacteria is most potent than free bacteria as shown in Table 1, the percentage of oil removal reaches to $28.8,36.8$ and $39.4 \%$ when using strains sp48, M12 and bacterial consortium, respectively at $1 \%$ oil concentration while it reaches to $46.73,45.016$ and $61.04 \%$ when immobilized on rice straw at the same conditions. These results illustrate that the bacterial consortium of sp48 and M12 strains are most potent for oil degradation than individual bacterium. Besides the best carrier for oil degradation is rice straw. The beneficial of employing mixed cultures consortium in bioremediation attributed to the effect of synergetic interactions among microorganisms of the consortium. It is possible that one bacterial species of the consortium removes the toxic metabolites produced by other bacterial species, that would delay activities and/or one species is able to degrade compounds others are not able to degrade or partially degrade them [26].

TABLE 1. \% of oil consumption using sp48 (Pseudomonas sp.) and M12 (Bacillus cereus) immobilized individually and its consortium on different carriers.

\begin{tabular}{lcccc}
\hline \multirow{2}{*}{ Different carriers } & \multicolumn{3}{c}{ \% of oil consumption } \\
\cline { 2 - 5 } & Physically* & \multicolumn{3}{c}{ Biologically** by immobilized } \\
\cline { 2 - 5 } & & $\mathbf{s p 4 8}$ & M12 & Bacterial consortium \\
\hline Rice straw & 88.049 & 46.73 & 45.016 & 61.04 \\
Cane leaves & 84.96 & 45.131 & 42.95 & 53.67 \\
Wood chips & 55.6 & 29.54 & 37.39 & 41.5 \\
Corn leaves & 81.44 & 33.147 & 39.96 & 60.26 \\
Foam & 98.03 & 15.5 & 12.54 & 18.42 \\
Wax & 96.37 & 0 & 0 & 0 \\
Free cells & - & 28.8 & 36.8 & 39.4 \\
\hline
\end{tabular}

*Physically: means adsorptions of oil on the surface of carrier.

**Biologically: means degradation of oil by bacteria immobilized on carrier without the effect of oil adsorption on the surface of carrier. 
The characteristics of suitable carrier materials should preferably include the following; the carrier should not be soluble, exhibit high stability, not readily degraded, be a natural product, easily available and economical [16, 27]. And these characteristics were found in the selected natural carriers specially rice straw which represents as an agriculture waste and makes a serious problem in the environment by burning. This became a controversial source of visible pollution because of the high visibility and potential hazard of the smoke. Hence, rice straw was selected in the immobilization of bacterial consortium in subsequent experiments in this work.

There are several studies reporting that immobilized cells showed a faster degradation rate than free cells [28-31]. The better and faster degradation rate observed was most likely due to the high immobilization efficiency of the cells onto the immobilization material and the high attraction between the hydrophobic immobilization material and the substrates. These lead to improving availability of the substrates for the cells and a better contact between the substrates and the immobilized cells, synergistically increasing the degradation rate [18, 29-33].

Investigation the optimal immobilization conditions

By testing different consortium preculture concentrations, it was found the $\%$ of oil degradation increased to $59.8 \%$ with the increasing the bacterial preculture concentrations 2, 3, and $4 \%$. On the other hand by increasing the culture concentration over $4 \%$, the $\%$ of oil degradation reaches to steady state as shown in Fig. 1. From these results the preculture concentration $4 \%$ (2
mL culture: $1.5 \mathrm{~mL}$ distal water; in $50 \mathrm{~mL}$ medium) was selected for the further work. Similarly Arafa et al [33] studied different inocula intervals ( $2 \%$, $4 \%$ and $6 \%$ ) and found that the biodegradation rate of oil sludge reaches to maximum amount $89.8 \%$ using $6 \%$ inoculum size of bacterial consortium after 12 days.

On the other hand by studying different bacterial incubation time with rice straw, the results showed that when the carrier material was incubated for $3 \mathrm{~h}$, the $\%$ of oil degradation reaches to $54 \%$. No significant increase in oil degradation was observed at longer incubation time (Table 2). The optimum incubation period necessary for the development of a well-established formulation was determined to be $3 \mathrm{~h}$. Similar observation was reported by Farag et al [32] by using isolate AQ1 (Candida tropicalis) immobilized by thin and thick wood chips the \% of oil consumption by immobilized AQ1 at incubation time $3 \mathrm{~h}$ reached to 74 and 64.2 respectively.

Furthermore Quek et al [13] reported that a well-established formulation could be generated by incubating polyurethane foam with a bacterial culture for $96 \mathrm{~h}$. A longer incubation period is inconvenient and less economical for the generation of a formulation. Other results showed that F9 cells could stably attach and be immobilized onto the carrier material (chitosan) within $4 \mathrm{~h}$ [23]. The electronic attraction between the negatively charged bacterial surfaces and the positively charged chitosan might explain why a shorter incubation period was sufficient for attachment. This shorter incubation period may make this compound carrier material advantageous in future scale-up for industrial production [23].

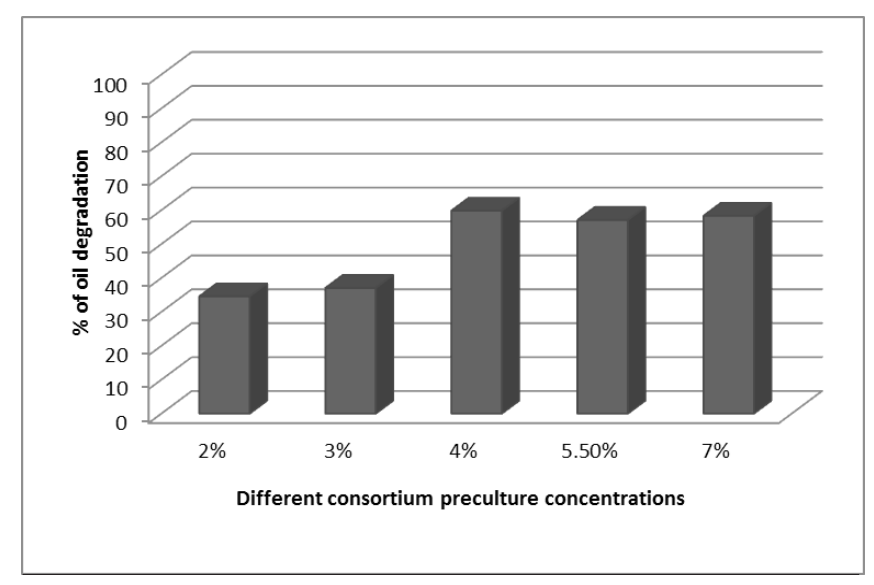

Fig. 1. \% of oil degradation using different concentrations of consortium. The ratio of culture to distilled water: $(2 \% ; 1: 2.5 \mathrm{~mL}) ;(3 \% ; 1.5: 2 \mathrm{~mL}),(4 \% ; 2: 1.5 \mathrm{~mL}),(5.5 \% ; 2.75: 0.75 \mathrm{~mL}),(7 \% ; 3.5 \mathrm{~mL}$ culture $)$ in $50 \mathrm{~mL}$ medium.

Egypt. J. Chem. 61, No. 6 (2018) 
The results of enumeration of viable cells immobilized on rice straw showed that, when the carrier material was incubated for $3 \mathrm{~h}$, the number of immobilized viable cells reached 6 X 109 CFU/ gm. An increase in the number of viable cells at longer incubation periods was insignificantly affected oil removal as represented in Table 2 . This result ensures that the optimum incubation period necessary for the development of a wellestablished formulation was $3 \mathrm{~h}$. Similar result was represented by Dengyong et al [23], where the carrier material was incubated with the F9 culture for various periods of time, and the viable cells immobilized on the carrier material were counted. His results showed that when the carrier material was incubated for $4 \mathrm{~h}$, the number of immobilized viable cells reached $5 \times 10^{9} \mathrm{CFU} / \mathrm{g}$. No significant increase in the number of viable cells was observed at longer incubation periods.

Assessment of immobilized bacterial consortium efficiency

The results showed that with increasing the concentration of crude oil the removal percentage decreased which could be rendered to the slow rate of biodegradation or the inhibitional effect of higher crude oil concentrations on the testing bacteria. The immobilized bacterial consortium on rice straw is more efficient than that immobilized in the foam. The percentages of biological oil removal using bacterial consortium immobilized on rice straw and foam at $1 \%$ oil concentration reach $61.6 \%$ and $15.4 \%$, respectively and the percentage decreased to $29.8 \%$ and $12.5 \%$, respectively at $4 \%$ oil concentration.

The combination of both techniques biological/ physical oil removal showed that the oil removal reaches a maximum percentage $97.14 \%$ and $98.2 \%$ using rice straw and foam respectively at $1 \%$ oil concentration and the percentage decreased slowly to reach $92.3 \%$ and $89.37 \%$ when using rice straw and foam respectively at $4 \%$ oil concentration. These results due to the synergistic effect of two techniques together as shown in Table 3 . We conclude that the combination of two techniques in case of rice straw as carrier is better than foam as carrier due to higher efficiency of biological degradation by bacterial consortium when immobilized on rice straw than foam.

Biologically means: degradation of oil by bacteria immobilized on carrier without the effect of oil adsorption on the surface of carrier. Biologically\& physically means: degradation of oil by bacteria immobilized on carrier in addition the effect of oil adsorption on the surface of carrier.

\section{Tracking of crude oil degradation}

Monitoring of crude oil removal rate biologically along 12 days incubation time is the best way to measure bioremediation efficiency of immobilized bacterial consortium. The results represent that by increasing time the biodegradation rate of crude oil increased and reach $61,68.49$, $71.3 \%$ after $6,9,12$ days respectively as shown in Fig. 2. No significant increase in degradation was observed after 9 days. Similar observation was reported by Dengyong et al [23], who indicated that the majority of the diesel oil was degraded within the first 7 days using immobilized F9 cells on chitosan. Also in other study they were found that the rate of biodegradation of total petroleum hydrocarbon (TPH) was high during the first 7 days of incubation reaching to $54 \%$ and then decreased thereafter reaching to $78 \% \mathrm{TPH}$ removal within 24 days of incubation period by using a consortium of degrading bacteria [26]

TABLE 2. \% of oil degradation and viable cell counts at different incubation time of bacterial consortium with rice straw.

\begin{tabular}{c|c|c}
\hline $\begin{array}{c}\text { Different incubation time of } \\
\text { culture with carrier by hour (h) }\end{array}$ & \% of oil degradation & CFU/g dry formulation \\
\hline 1 & 49.04 & $5.8 \times 10^{9}$ \\
2 & 49.2 & $5.9 \times 10^{9}$ \\
3 & 53.37 & $6 \times 10^{9}$ \\
4 & 54.13 & $6.08 \times 10^{9}$ \\
5 & 54.27 & $6.16 \times 10^{9}$ \\
\hline
\end{tabular}


TABLE 3. \% of oil consumption using immobilized consortium at different oil concentrations.

\begin{tabular}{ccccc}
\hline \multirow{2}{*}{$\begin{array}{c}\text { Different oil } \\
\text { Concentrations }\end{array}$} & \multicolumn{2}{c}{$\%$ of oil removal using rice straw } & \multicolumn{2}{c}{$\%$ of oil removal using foam } \\
\cline { 2 - 4 } & Biologically & $\begin{array}{c}\text { Biologically } \& \\
\text { physically }\end{array}$ & Biologically & $\begin{array}{c}\text { Biologically \& } \\
\text { physically }\end{array}$ \\
\hline $1 \%$ & 61.6 & 97.14 & 15.47 & 98.2 \\
$2 \%$ & 46.67 & 95.59 & 15 & 91.95 \\
$3 \%$ & 37.1 & 93.6 & 14.25 & 91.15 \\
$4 \%$ & 29.8 & 92.3 & 12.59 & 89.37 \\
\hline
\end{tabular}

Biologically means: degradation of oil by bacteria immobilized on carrier without the effect of oil adsorption on the surface of carrier. Biologically\& physically means: degradation of oil by bacteria immobilized on carrier in addition the effect of oil adsorption on the surface of carrier.

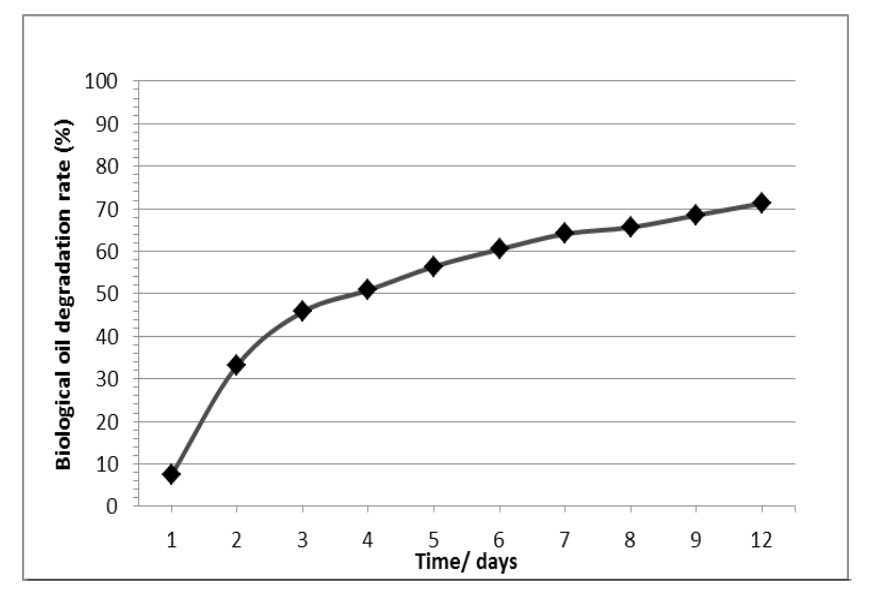

Fig. 2. Crude oil degradation rate using immobilized bacterial consortium.

Microscopic examination by Scanning Electron Microscope (SEM)

The morphology of the rice straw was examined under scanning electron microscope (Fig. 3 A). The results revealed that the rice straw is a porous carrier. The pores of the carrier material provided suitable and protective niches for bacteria. The bacterial cells were attached to the walls of the pores (Fig. 3 B) the pores may protect immobilized bacterial cells from antagonistic environmental factors. Figure (3 C) exposes that the bacterial diameter approximately $(1.9-1 \mu \mathrm{m})$ and $(5.5-0.8 \mu \mathrm{m})$ for bacterial consortium (strains sp48 and M12). Figure (3 D) shows the attachment of crude oil on the surface of rice straw.

Optimization of oil removal by immobilized bacterial consortium in bioreactor

The assessments of oil removal using bacterial consortium immobilized on rice straw in a

Egypt. J. Chem. 61, No. 6 (2018) bioreactor at different times were represented in Fig. 4 , which shows that the $\%$ of oil consumption increased by increasing the time in the two cases biologically and biologically/ physically which reach $63 \%$ and $90 \%$ respectively after 12 days. This indicates that the $\%$ of consumption increased considerably in case of biologically/ physically than biologically alone.

The behaviors depicted in Fig. 5 represent that the $\%$ of oil degradation biologically increased to $56.2 \%$ with increasing the rice straw weight to $1.6 \mathrm{gm}$ after 6 days of incubation. As well by increasing the rice weight the $\%$ of oil consumption biologically/ physically increased and reaches to $87.2 \%$ when using $1.6 \mathrm{gm}$. From this result the rice weight $1.6 \mathrm{gm}$ was selected for the further work which gives a comparable result instead of increasing the time. 

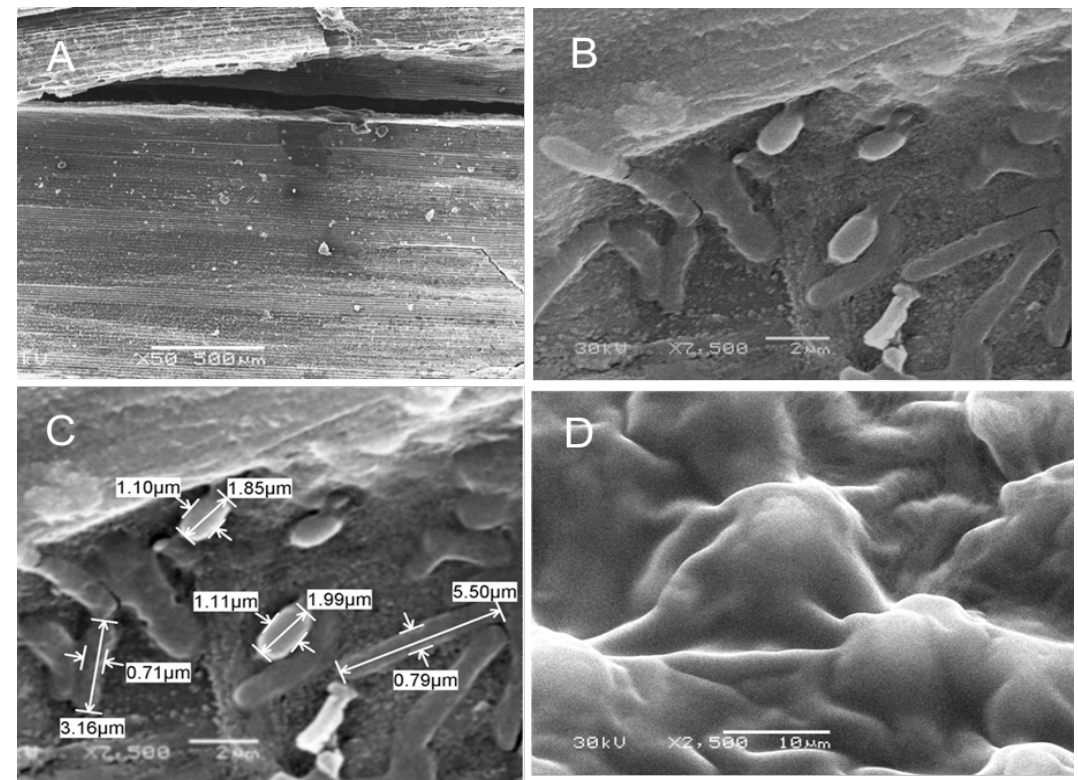

Fig. 3. Scanning Electron Micrograph (SEM), A: Structure of rice straw particles at X50,500; B, C: Bacterial consortium immobilized on rice straw surface at X2,500, D: Attachment of crude oil on the surface of rice straw as a carrier material at $\mathrm{X} 2,500$.

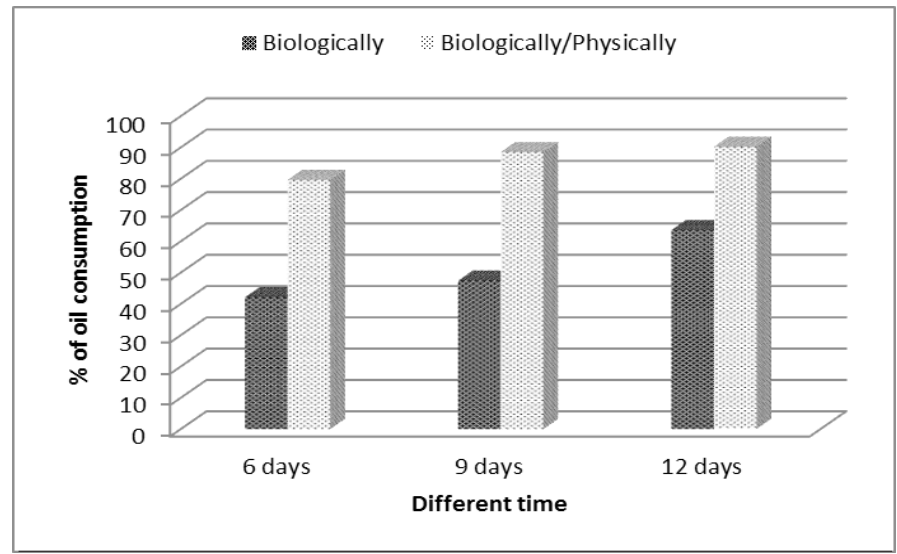

Fig. 4. Crude oil consumption \% biologically and biologically/ physically at different time of incubation.

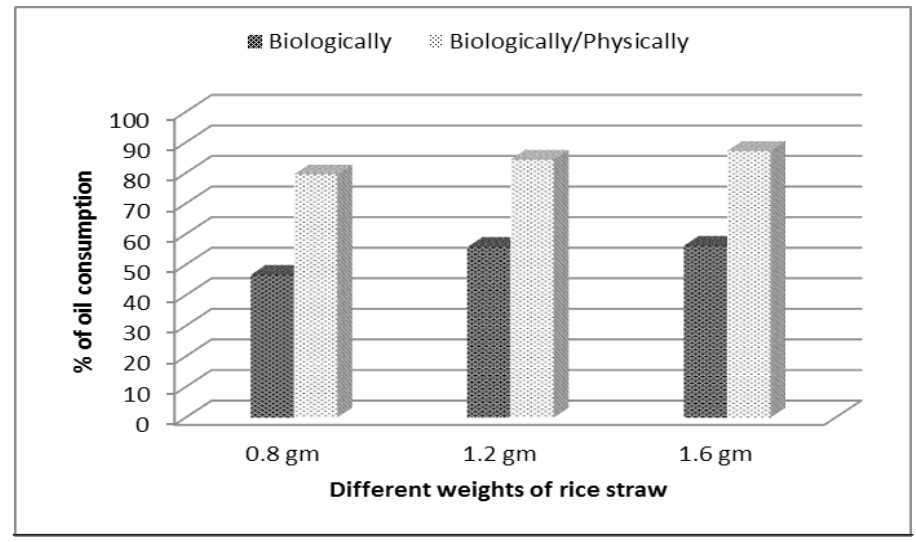

Fig. 5. Crude oil consumption \% biologically and biologically/physically at different weights of rice straw.

Egypt. J. Chem. 61, No. 6 (2018) 
Efficiency of immobilized bacterial consortium under continuous addition of oil in bioreactor

The experimental data revealed that the \% of oil consumption biologically/ physically decreased with continuous adding of $1 \%$ crude oil from $87.3 \%$ to $83.28 \%$ and $81.27 \%$ after three times of addition and the incubation time interval was 3 days. This indicates the great ability of immobilized bacteria to remove oil, so it can be applied in nature and give a good result.

The same result was represented by Qingxin et al [34] which showed that the immobilized cells of strain Bacillus sp. M-12 could be reused for many cycles. The immobilized M-12 by (polyvinyl alcohol) PVA could be used for more than seven cycles to treat waste water using a semi-continuous operation system. In each cycle, when the COD removal reached about or more than $70 \%$, the waste water in the flask was removed and the immobilized cells retained. New waste water was then added into the flask and the COD of the waste water reduced from 2600 to $240 \mathrm{mg} / \mathrm{L}$. Similarly Nichakorn et al [35] reported that the effectiveness of chitosan-immobilized cells (Sphingobium sp. P2) was investigated in a semi-continuous treatment system, where the stock oil/water emulsion of PTTV120 lubricant was added daily to the synthetic wastewater to maintain the initial lubricant concentration of 200 $\mathrm{mg} / \mathrm{L}$. The concentration of TPH in the control treatment increased daily and equaled $996 \pm 8$ $\mathrm{mg} / \mathrm{L}$ at the end of study, this value corresponded to the total amount of added lubricant. In contrast, the lubricant was significantly removed from the systems with chitosan-immobilized cells, killed-immobilized cells and free cells, where the amounts of residual TPH were $214 \pm 4,450 \pm 2$ and $605 \pm 4 \mathrm{mg} / \mathrm{L}$ at the end of study, respectively. The efficiency of lubricant degradation was maximum at chitosan-immobilized cells.

\section{Conclusions}

Crude oil biodegradation by immobilized bacterial consortium is considered a valid process and has a high positive impact in oil environmental contaminants removal. In this study the rice straw represents the best carrier for bacterial immobilization. By studying different immobilization conditions as bacterial concentrations, incubation time with carrier, and $\%$ of oil concentration. It was found that $4 \%$ bacterial preculture, $3 \mathrm{~h}$ incubation time, and $1 \%$ oil concentration are the finest conditions where oil removal reached to $61.6 \%$ and $97.14 \%$ Egypt. J. Chem. 61, №. 6 (2018) biologically and biologically/ physically, respectively. By applying the same conditions in a small scale bioreactor the crude oil degradation by bacterial consortium reached to $56.2 \%$ and oil consumption biologically/ physically reached to $87.2 \%$ while three times addition of $1 \%$ oil concentration the removal reached to $81.27 \%$. All these approaches proof that the immobilization process more applicable and environmentally viable mitigation technology.

\section{Acknowledgments}

This work was financially supported by the project grant from the Egyptian Science and Technology Development Fund, STDF, Egypt (Grant No. 1196).

\section{References}

1. Gesinde A.F., Agbo E.B., Agho M.O. and Dike E.F.C., Bioremediation of some Nigerian and Arabian crude oils by fungal isolates, International Journal of Pure and Applied Sciences, 2 (3), 37-44 (2008).

2. Law A.T. and Button D.K., Multiple-carbon-source limited growth kinetics of a marine cory form bacterium, Journal of Bacteriology, 129 (1), 115-123 (1977).

3. Del'Arco J.P. and de França F.P., Biodegradation of crude oil in sandy sediment, International Biodeterioration \& Biodegradation, 44, 87-92 (1999).

4. Xu R., Lau N.L.A., Ng K.L. and Obbard J.P., Application of a slow-release fertilizer for oil bioremediation in beach sediment, Journal of Environmental Quality, 33, 1210-1216 (2004).

5. Madigan M.T., Martinko, J.M. and Parker, J., Brock Biology of Microorganisms, ninth ed. Prentice-Hall International Ltd., London (2000).

6. Hii Y.S., Law Ah.T., Shazili N.A.M., AbdulRashid M.K. and Lee C.W., Biodegradation of Tapis blended crude oil in marine sediment by a consortium of symbiotic bacteria, International Biodeterioration \& Biodegradation, 63, 142-150 (2009).

7. Ito H., Hosokawa R., Morikawa M. and Okuyama H., A turbine oil-degrading bacterial consortium from soils of oil fields and its characteristics, International Biodeterioration \& Biodegradation, 61, 223-232 (2008).

8. Li X., Li P., Lin X., Zhang C., Li Q. and Gong Z., Biodegradation of aged polycyclic aromatic 
hydrocarbons (PAHs) by microbial consortia in soil and slurry phases, Journal of Hazardous Materials, 150 (1), 21-26 (2008).

9. Radwan S.S., Al-Hasan R.H., Ali N., Salamah S. and Khanafer M., Oil-consuming microbial consortia floating in the Arabian Gulf, International Biodeterioration \& Biodegradation, 56, 28-33 (2005).

10. William P.S., Review of Oil Spill Responses on Moderately-sized Spills in US Waters from 19932000. Regional Citizens; Advisory Council, Elise De Cola (2001).

11. Ro K. S., Breitenbeck G. A. and Ghalambor A., Composting Technology for Practical and Safe Remediation or Oil Spill Residuals. Louisiana Oil Spill Coordinator's Office/Office of governor. Louisiana Applied Oil Spill Research and Development Program, Baton Rouge, Louisiana. Technical Report Series, 97-009 (1998).

12. Gonzalez E.C., Avelizapa L.I.R., Camarillo R.C. and Avelizapa N.G.R., Effect of keratinous waste addition on improvement of crude oil hydrocarbon removal by a hydrocarbon-degrading and keratinolytic mixed culture, International Biodeterioration \& Biodegradation, 63, 1018-1022 (2009).

13. Quek E., Ting Y.P. and Tan H.M., Rhodococcus sp. F92 immobilized on polyurethane foam shows ability to degrade various petroleum products, Bioresource Technology, 97, 32-38 (2006).

14. Van V.J.A., Van O.L.S. and Van E.J.D., Fate and activity of microorganisms introduced into soil, Microbiology and Molecular Biology Reviews, 61, 121 - 135 (1997).

15. Mohsen R.M., Abdel-Mohsen F.F., Deghiedy N.M. and Abu-Ayana Y.M., Review on the Manufacture of Particleboard from Agro-Wastes Using Different Adhesives, Egyptian Journal of Chemistry, 57, 165-176 (2014).

16. Leenen E.J.T.M., Dos Santos V.A.P., Grolle K.C.F., Tramper J. and Wijffels R., Characterisitics of and selection criteria for support materials for cell immobilization in wastewater treatment, Water Research, 30, 2985-2996 (1996).

17. Gentili A.R., Cubitto M.A., Ferrero M. and Rodriguez M.S., Bioremediation of crude oil polluted seawater by a hydrocarbon degrading bacterial strain immobilized on chitin and chitosan flakes, International Biodeterioration \& Biodegradation, 57, 222-228 (2006).
18. Wilson N.G. and Bradley G., Enhanced degradation of petroleum (slovene diesel) in an aqueous system by immobilized Pseudomonas fluorescens, Journal of Applied Microbiology, 80, 99-104 (1996).

19. Obuekwe C.O. andAl-Muttawa E.M., Self-immobilized bacterial cultures with potential for application as ready-to-use seeds for petroleum bioremediation, Biotechnology Letters, 23, 1025 -1032 (2001).

20. Oh Y.S., Maeng J. and Kim S.J., Use of microorganism immobilized polyurethane foams to absorb and degrade oil on water surface, Applied Microbiology and Biotechnology, 54, 418-423 (2000).

21. Law A.T. and Teo K.S., Oil biodegradation in the Straits of Malacca: Phenanthrene degradation by AR-3, Journal of Marine Biotechnology, 5, 162-167 (1997).

22. Giorgio T. and Jan H. C. A., Tucker model based approach for analysis of complex oil biodegradation data, Journal of Chromatography A, 1216, 7865-7872 (2009).

23. Dengyong H., Xianrong S., Qun L., Ying H., Qingrong W. and Qiong L., Enhancement of the diesel oil degradation ability of a marine bacterial strain by immobilization on a novel compound carrier material, Marine Pollution Bulletin, 67, 146-151 (2013).

24. Mang L., Zhongzhi Z., Shanshan S., Qinfang W. and Weizhang Z., Enhanced degradation of bioremediation residues in petroleum-contaminated soil using a two-liquid-phase bioslurry reactor, Chemosphere, 77, 161-168 (2009).

25. Nawaz M.S., Billedeau S.M. and Cerniglia C.E., Influence of selected physical parameters on the biodegradation of acrylamide by immobilized cells of Rhodococcus sp., Biodegradation, 9, 381-387 (1998).

26. Amer R., El-Gendy N. Sh., Taha T., Farag S. and Abdel Fattah Y., Biodegardation of crude oil and its kinetics using indigenous bacterial consortium isolated from contaminated area in Egyptian Mediterranean ecosystem, Jokull Journal, 64 (4), 42-58 (2014).

27. Lorda G.S. and Balatti A.P., Designing media I. Production of high cell concentrations of Rhizobium and Bradyrhizobium. In Legume Inoculants. Selection and Characterization of Strains Production, Use and Management, eds

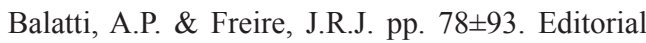
Kingra, Buenos Aires (1996).

Egypt. J. Chem. 61, No. 6 (2018) 
28. Wang J. and Qian Y., Microbial degradation of 4-chlorophenol by microorganisms entrapped in carregeenan-chitosan gels, Chemosphere, 38, 3109-3117 (1999).

29. Yamaguchi T., Ishida M. and Suzuki T., An immobilized cell system in polyurethane foam for the lipophilic micro-alga Protothecazopfii, Process Biochemistry, 34, 167-171 (1999).

30. Na K., Lee Y., Lee W., Huh Y., Lee J., Lee J., Kubo M. and Chung S., Characterization of PCBdegrading bacteria immobilized in polyurethane foam, Journal of Bioscience and Bioengineering, 90, 368-373 (2000).

31. Diaz M.P., Boyd K.G., Grigson S.J.W. and Burgess J.G., Biodegradation of crude oil across a wide range of salinities by an extremely halotolerant bacterial consortium MPD-M, immobilized onto polypropylene fibers, Biotechnology and Bioengineering, 79, 145-153 (2002).

32. Farag S., Soliman N.A. andAbdel-Fattah Y.R., Optimization of Immobilization Conditions for Petroleum Oil Biodegradation by Candida tropicalis AQ1 using Wood
Chips and Wax, Research Journal of Pharmaceutical, Biological and Chemical Sciences, 7(5), 200-210 (2016).

33. Arafa A., Farag S., Mahdaly M.A. and Badr M.M., Biodegradation of Petroleum Industry Oily Sludge by Bacterial Consortium and Its Application in Land Farming, Pakistan Journal of Biotechnology, 13 (1), 1-11 (2016).

34. Qingxin L., Congbao K. and Changkai Z., Waste water produced from an oil field and continuous treatment with an oil-degrading bacterium, Process Biochemistry, 40, 873- 877 (2005).

35. Nichakorn K., Sitti T., Onruthai P., Sorawit P., Thawach C., Chalermchai R. and Ekawan L., Airlift bioreactor containing chitosan-immobilized Sphingobium sp. P2 for treatment of lubricants in wastewater, Journal of Hazardous Materials, 213, 466-473 (2012).

Received 16/5/2018; accepted 15/7/2018)

انسكابات النفط إلى جانب التخلص من منتجات النفط و ألقائها مباشرة في البيئة هي من المصادر الرئيسيه لتلوث

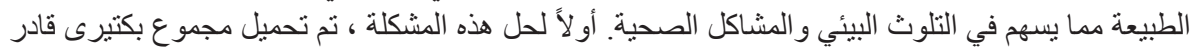

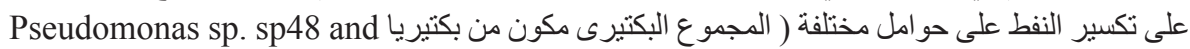
Bacillus cereus M12

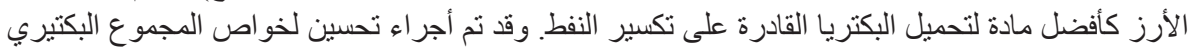

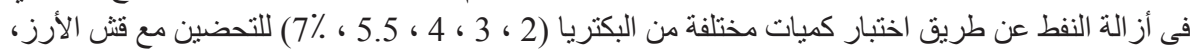

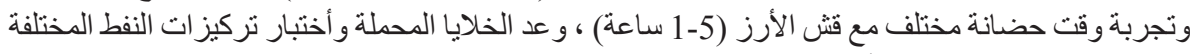

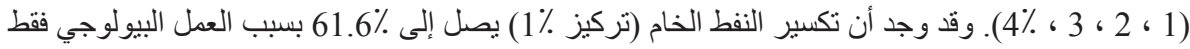

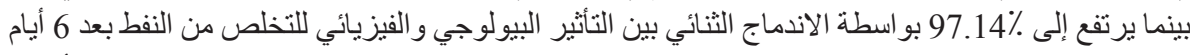

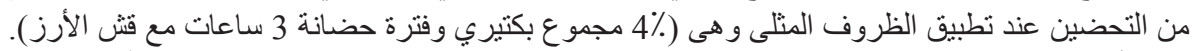

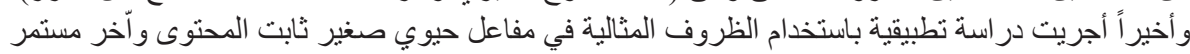

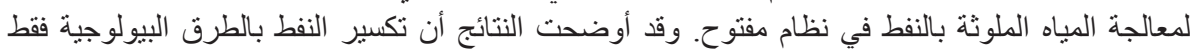

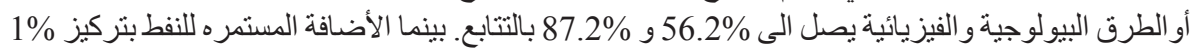

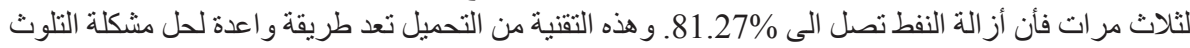
بالنفط بسبب التأثير المشترك لكلاً من الطرق الفيز الفيائية والبيولوجية. 